\title{
KOMBINASI PUPUK ORGANIK HAYATI DAN PUPUK FOSFAT UNTUK PENINGKATAN KERAGAAN BIBIT KELAPA SAWIT (Elaeis guineensis Jacq)
}

\section{Combination of Bio-organic Fertilizer and Phosphate Fertilizer on Improving Performance of Oil Palm Seedlings (Elaeis guineensis Jacq).}

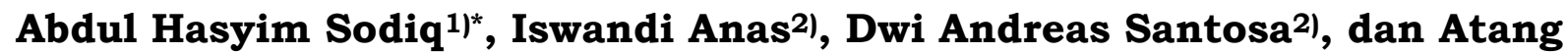 \\ Sutandi2) \\ 1) Alumni Program Studi Bioteknologi Tanah dan Lingkungan, Sekolah Pascasarjana IPB, Jl. Raya Darmaga, \\ Gedung Andi Hakim Nasoetion Kampus IPB Darmaga Bogor 16680 \\ 2) Departemen Ilmu Tanah dan Sumberdaya Lahan, Fakultas Pertanian IPB, J1. Meranti Kampus IPB Darmaga \\ Bogor 16680
}

\begin{abstract}
This experiment was conducted to determine the effect of bio-organic fertilizer on improving performance of oil palm seedlings, the total microbial population and population of phosphate solubilizing microbial in oil palm seedlings. Preparation of planting medium was done by taking the top soil with maximum depth of $25 \mathrm{~cm}$. The top soil was air dried and grounded then put into each polybag with a volume of $5 \mathrm{~kg}$. The parameter of oil palm seedlings was observed at week 4 to the 22 after planting (WAP) in the experimental garden greenhouse Cikabayan, Darmaga. The experiment was conducted in randomized block design (RBD) totest the capacity of microbial to dissolve phosphate that composed of two factors with three replications. The results showed the use of rock phosphate fertilizer on plant height showed better results compared to the use of SP-36 and statistical analysis the single effect of bio-organic fertilizer the effect organic fertilizer to total soil microbial population showed the best results.
\end{abstract}

Keywords: Bio-organic fertilizers, oil palm seedlings, organic fertilizers, phosphate solubilizing microbial, total microbial population

\begin{abstract}
ABSTRAK
Percobaan ini dilakukan untuk mengetahui pengaruh pupuk organik hayati diperkaya mikrob tanah terhadap keragaan tanaman, populasi total mikrob dan populasi mikrob pelarut fosfat di pembibitan kelapa sawit. Persiapan media tanam dilakukan dengan mengambil lapisan tanah atas (topsoil) dengan kedalaman maksimal $25 \mathrm{~cm}$ kemudian tanah tersebut dikering anginkan dan dimasukkan ke dalam setiap kantong plastik media tanam dengan volume masing-masing $5 \mathrm{~kg}$. Pengukuran parameter keragaan tanaman bibit kelapa sawit dilakukan dari minggu ke-4 setelah tanam (MST) hingga ke-22 MST di rumah kaca kebun percobaan Cikabayan, Darmaga. Percobaan uji efektivitas mikrob pelarut fosfat (MPF) pada pupuk organik hayati menggunakan Rancangan Acak Kelompok (RAK), yang terdiri dari dua faktor dengan tiga ulangan. Hasil percobaan menunjukkan pengaruh penggunaan pupuk batuan fosfat terhadap tinggi tanaman memberikan hasil yang lebih baik dibandingan penggunaan SP-36 dan analisa statistik terhadap pengaruh tunggal pupuk organik hayati, pengaruh pupuk organik terhadap populasi total mikrob menunjukkan hasil terbaik.
\end{abstract}

Kata kunci: Pupuk organik hayati, bibit kelapa sawit, pupuk organik, mikrob pelarut fosfat, total populasi mikrob tanah.

\section{PENDAHULUAN}

Sejalan dengan pesatnya perkembangan perkebunan kelapa sawit di Indonesia baik perkebunan milik swasta, rakyat maupun pemerintah sudah pasti akan berdampak kepada tingginya permintaan akan pupuk anorganik. Pupuk anorganik mengandung unsur hara yang relatif tinggi serta lebih cepat tersedia bagi tanaman. Tingginya permintaan tersebut mengakibatkan harga pupuk akan terus meningkat dan berimbas kepada tingginya biaya produksi kelapa sawit.
Salah satu hal yang perlu dicermati adalah bahwa pemakaian pupuk anorganik secara terus menerus dengan dosis yang berlebihan memiliki dampak buruk terhadap kerusakan lingkungan dan penurunan keanekaragaman hayati tanah. Berkaitan dengan hal tersebut maka perlu dicari alternatif lain agar produksi kelapa sawit bisa ditingkatkan tanpa bergantung sepenuhnya pada pemakaian pupuk anorganik. Salah satu solusi adalah dengan penggunaan pupuk organik hayati (bio organic fertilizer) yang diperkaya mikrob tanah bermanfaat. 
Mikrob tanah diketahui dapat memproduksi fitohormon yang berfungsi untuk meningkatkan pertumbuhan perakaran, pertumbuhan tajuk dan kesehatan tanaman (Hindersah dan Simarmata, 2004). Menurut ElHabbasha et al. (2007) aplikasi pupuk hayati untuk menurunkan pemakaian pupuk anorganik penting dilakukan untuk melindungi lingkungan dari dampak buruk pupuk anorganik yang digunakan berlebihan. Pupuk organik hayati adalah kombinasi antara pupuk mikrob dan pupuk organik. Pupuk ini terbuat dari bahan-bahan alami seperti pupuk kandang, kompos dan kascing yang diperkaya dengan mikrob hidup yang memiliki peranan positif bagi tanaman. Pupuk hayati merupakan mikrob hidup yang diberikan kedalam tanah sebagai inokulan menyediakan unsur hara tertentu bagi tanaman. Beberapa mikrob tanah seperti Rhizobium, Azospirillum, Azotobacter, mikrob pelarut fosfat, mikrob penambat $\mathrm{N}_{2}$ adalah contoh mikrob yang sering digunakan untuk pupuk hayati dan sudah banyak tersedia di pasaran. Komunitas mikrob dapat berperan dalam pertumbuhan tanaman melalui beberapa mekanisme antara lain meningkatkan ketersediaan unsur hara didalam tanah, meningkatkan kemampuan bersaing terhadap hama dan penyakit yang ditularkan melalui perakaran (Smith dan Read, 1997).

Pemakaian pupuk organik hayati yang diaplikasikan dengan tepat dan benar akan berpengaruh positif terhadap ketersediaan unsur hara, ketahanan terhadap serangan penyakit dan meningkatkan kesehatan tanah sehingga pertumbuhan tanaman akan lebih baik dan hasil produksi dapat ditingkatkan. Pupuk organik hayati mampu meningkatkan efisiensi serapan hara, memperbaiki pertumbuhan dan meningkatkan komponen hasil produksi tanaman kedelai serta dapat meningkatkan ketahanan fisik tanaman kedelai terhadap serangan hama dan penyakit (Agung dan Rahayu, 2004).

Hardjowigeno (1995) menyatakan bahwa pemakaian pupuk organik selain menambahkan hara dapat pula memperbaiki struktur tanah, meningkatkan kapasitas tukar kation dan meningkatkan kegiatan biologi tanah. Salah satu kendala yang dihadapi saat ini adalah masih minimnya pengetahuan tentang penggunaan agen hayati baik jenis mikrob maupun interaksinya dengan tanaman. Lee et al. (2000) mengungkapkan interaksi mikrob penambat $\mathrm{N}_{2}$ dengan tanaman inang merupakan salah satu contoh peningkatan kualitas tanaman oleh mikrob. Oleh sebab itu penelitian tentang pemanfaatan mikrob tanah untuk budidaya perkebunan harus terus diteliti untuk mendapatkan hasil yang lebih baik dan optimal. Tujuan penelitian ini adalah memberikan informasi tentang efektifitas mikrob pelarut fosfat yang terdapat pada pupuk organik hayati dalam meningkatkan keragaan bibit kelapa sawit dan memberi informasi sumber pupuk fosfat yang efisien dalam meningkatkan keragaan bibit kelapa sawit.

\section{BAHAN DAN METODE}

Penelitian ini dilaksanakan di rumah kaca kebun percobaan IPB, Cikabayan-Darmaga, Bogor. Analisa populasi mikrob tanah dilakukan di Laboratorium Biologi Tanah (DITSL), Institut Pertanian Bogor.

Bahan yang digunakan dalam penelitian ini adalah pupuk organik hayati (Biost), pupuk organik dari kotoran sapi (Agro Flower), tanah Latosol Darmaga, benih kelapa sawit varietas DxP 540 dari PPKS Medan, batuan fosfat, pupuk SP-36, pupuk Urea, $\mathrm{KCl}$ dan Kiserit dan perlengkapan pendukung lainnya.

\section{Metode Penelitian}

Metode penelitian menggunakan rancangan faktorial dalam acak kelompok dengan 2 faktor yaitu pupuk organik hayati (I) dan sumber hara fosfat (II). Faktor I Pupuk organik hayati yang terdiri dari tiga taraf yaitu : B0 (Tanpa pupuk organik hayati), B1 (Pupuk

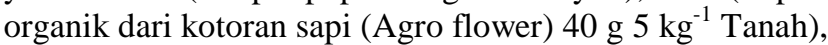

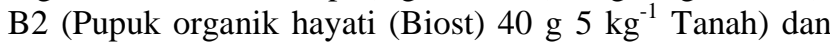
Faktor II Sumber hara dan dosis fosfat $(\mathrm{P})$ yang terdiri dari enam taraf yaitu : P1 (Batuan fosfat $50 \% 1.83 \mathrm{~g}^{2} \mathrm{~kg}^{-1}$

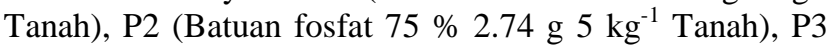

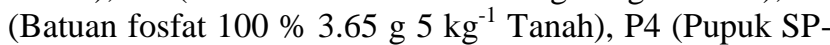

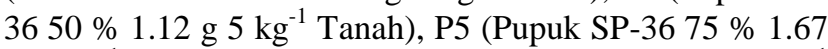

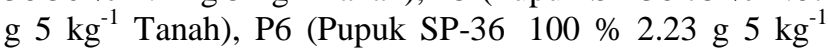
Tanah).

Tabel 1. Kombinasi perlakuan pupuk organik hayati dengan sumber dan dosis fosfat

\begin{tabular}{ccccccc}
\hline $\begin{array}{c}\text { Perlakuan Pupuk } \\
\text { Organik Hayati }\end{array}$ & P1 & P2 & P3 & P4 & P5 & P6 \\
\hline B0 & B0P1 & B0P2 & B0P3 & B0P4 & B0P5 & B0P6 \\
B1 & B1P1 & B1P2 & B1P3 & B1P4 & B1P5 & B1P6 \\
B2 & B2P1 & B2P2 & B2P3 & B2P4 & B2P5 & B2P6 \\
\hline
\end{tabular}

B0 (Tanpa pupuk organik hayati), B1 (Pupuk organik dari kotoran sapi, B2 (Pupuk organik hayati (Biost); P1 (Batuan fosfat $50 \%$, P2 (Batuan fosfat $75 \%$, P3 (Batuan fosfat $100 \%$ ), P4 (Pupuk SP-36 50\%, P5 (Pupuk SP-36 $75 \%$, P6 (Pupuk SP-36 $100 \%$ ).

Setiap perlakuan diujikan terhadap 4 bibit kelapa sawit dan diulang sebanyak 3 kali, sehingga diperoleh 216 tanaman percobaan. Pada aplikasi pemupukan dilakukan juga pemupukan dasar (Urea, $\mathrm{KCl}$ dan Kiserit) berdasarkan dosis anjuran teknologi budidaya kelapa sawit (Kiswanto et al., 2008).

\section{Analisis Data}

Data yang diperoleh dianalisa secara statistik menggunakan Analysis of Variance (ANOVA) pada selang kepercayaan $5 \%$. Analisis statistik dilanjutkan terhadap perlakuan yang berpengaruh nyata dengan menggunakan uji Duncan Multiple Range Test (DMRT) pada taraf nyata $5 \%$ (Mattjik dan Sumertajaya, 2006).

\section{HASIL DAN PEMBAHASAN}

\section{Peubah Keragaan Tanaman}

\section{Diameter Bonggol}

Hasil pengamatan pertumbuhan diameter bonggol selama penelitian dapat dilihat pada Gambar 1. Hasil pertumbuhan diameter bonggol terbaik diperlihatkan oleh perlakuan peggunaan pupuk organik dengan SP-36 $100 \%$ (B1P6). Hal ini membuktikan bahwa pupuk SP-36 adalah pupuk fosfat yang mudah tersedia bagi tanaman terlebih bila aplikasinya bersamaan dengan penggunaan pupuk organik maupun pupuk organik hayati.

Berdasarkan Gambar 1 kombinasi perlakuan pupuk organik dan pupuk organik hayati dengan batuan fosfat lebih berpengaruh dalam meningkatkan diameter bonggol 
tanaman kelapa sawit bila dibandingkan dengan pemberian pupuk batuan fosfat tunggal tanpa kombinasi dengan penggunaan pupuk organik/hayati. Terbukti dengan hasil diameter terbaik bonggol kelapa sawit yang ditunjukkan oleh (B1P6) yaitu sebesar $18.15 \mathrm{~mm}$, sementara diameter

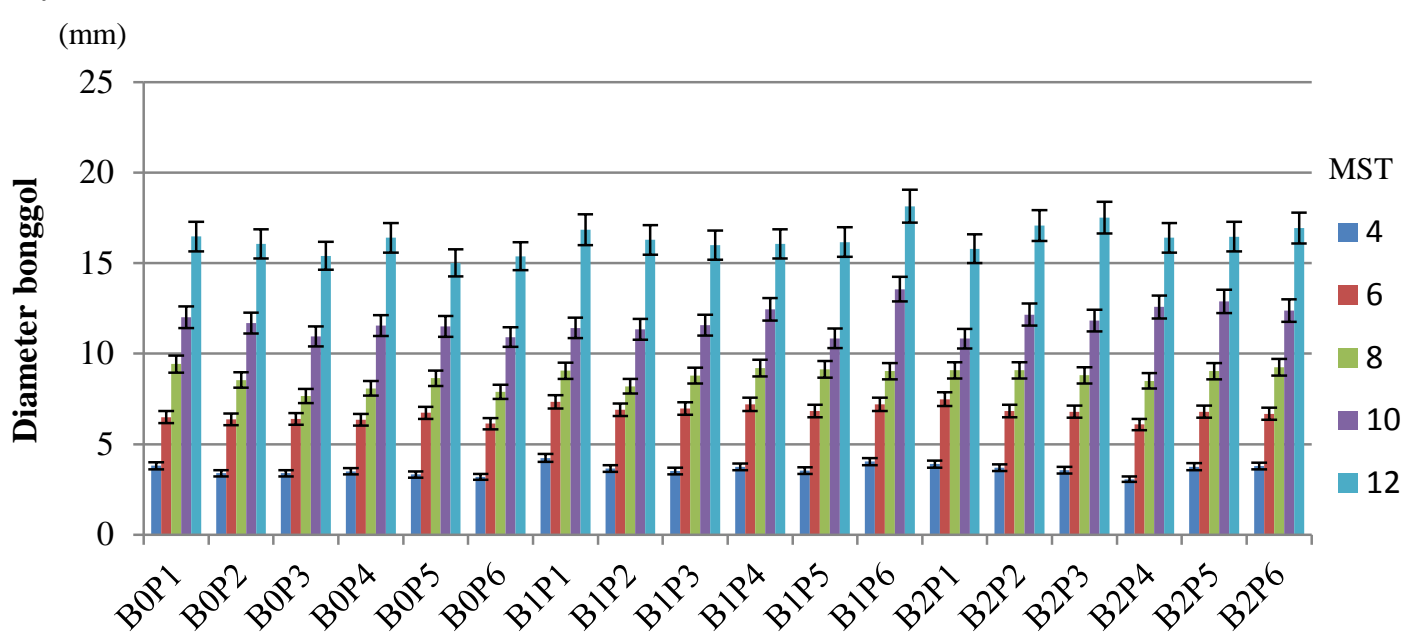

Perlakuan terendah yaitu $15.01 \mathrm{~mm}$ ditunjukkan oleh perlakuan SP36 pada dosis $75 \%$ (B0P5).

Gambar 1. Pengaruh pupuk organik hayati pelarut fosfat terhadap diameter bonggol bibit kelapa sawit pada 4 - 12 MST

Selanjutnya masih ditunjukkan oleh Gambar 1 yaitu perlakuan kombinasi pupuk organik dan organik hayati dengan taraf dosis SP-36 menunjukkan pengaruh terhadap pertambahan diameter bonggol tanaman kelapa sawit yang lebih tinggi jika dibandingkan dengan pemberian SP-36 tunggal. Hal ini membuktikan walaupun pupuk SP-36 merupakan pupuk fosfat yang mudah tersedia namun tanpa aplikasi bersamaan dengan pupuk organik/organik hayati diduga SP-36 belum dapat mendukung pertumbuhan tanaman kelapa sawit secara optimal. Menurut Smith et al. (1993) bahan organik merupakan sumber utama hara makro seperti $\mathrm{N}, \mathrm{P}$ dan $\mathrm{S}$ dan unsur hara mikro esensial lainnya yang sangat penting bagi pertumbuhan tanaman.

\section{Tinggi Tanaman}

Hasil pengamatan laju pertumbuhan tinggi tanaman selama 12 MST dengan hasil tertinggi $46.80 \mathrm{~cm}$ ditunjukkan oleh perlakuan penggunaan pupuk organik hayati dengan dosis pupuk batuan fosfat $100 \%$ (B2P3). Hal tersebut diduga karena adanya peningkatan efektifitas mikrob tanah pada aplikasi perlakuan penggunaan pupuk organik hayati. Hasil terbaik berturut-turut selanjutnya ditunjukkan oleh perlakuan penggunaan pupuk organik hayati pada berbagai dosis SP-36. Hal ini sejalan dengan pernyataan bahwa efisiensi pupuk $\mathrm{P}$ dapat lebih ditingkatkan melalui pemberian bahan organik dimana dekomposisi bahan organik dalam tanah dapat meningkatkan efisiensi pupuk $\mathrm{P}$ sebanyak 1.5 sampai 2 kali lipat (Adiningsih, 1992).

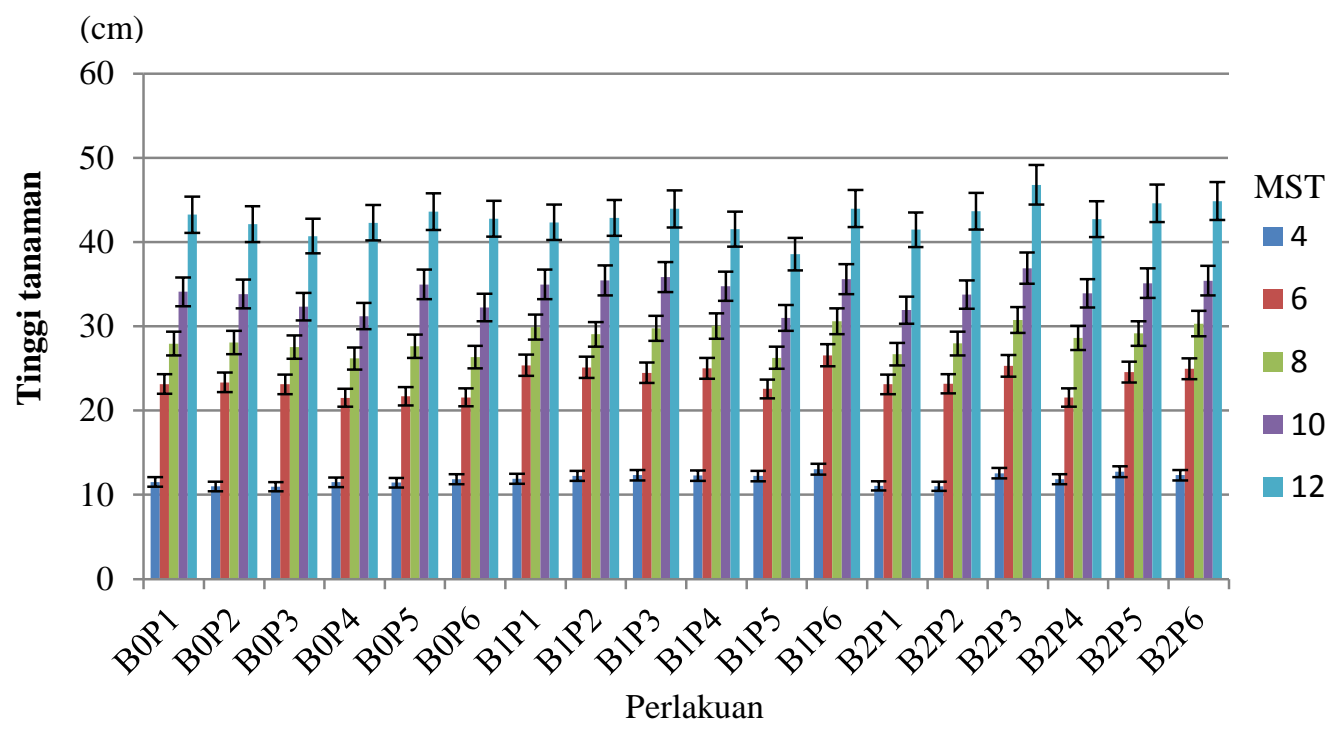

Gambar 2. Pengaruh pupuk organik hayati pelarut fosfat terhadap tinggi bibit kelapa sawit pada 4 - 12 MST 
Pertumbuhan tinggi tanaman seperti yang ditunjukkan pada Gambar 2 membuktikan bahwa penggunaan pupuk organik/organik hayati menunjukkan hasil yang lebih baik dibandingkan perlakuan tanpa penggunaan pupuk organik. Hal ini karena karbon (C) dari pupuk kandang/organik dapat digunakan oleh mikrob sebagai sumber energi dan penyusun tubuhnya (Subba Rao, 1994). Diketahui meningkatnya populasi dan aktivitas mikrob di dalam tanah karena pemberian pupuk kandang (Boggs et al., 2000).

\section{Jumlah Pelepah Daun}

Ditunjukkan pada Gambar 3, pertumbuhan jumlah pelepah daun bibit kelapa sawit akibat kombinasi perlakuan pupuk organik dan organik hayati dengan batuan fosfat lebih baik bila dibandingkan dengan perlakuan pupuk batuan fosfat saja. Sementara pada kombinasi pupuk organik dengan SP-36 lebih baik dalam meningkatkan pertumbuhan pelepah daun kelapa sawit dibandingkan semua perlakuan yang diberikan (Gambar 3). Semakin banyak jumlah pupuk organik dan SP-36 yang diberikan pada tanah, semakin banyak jumlah P-tersedia dalam tanah untuk tanaman (Soepardi, 1983).

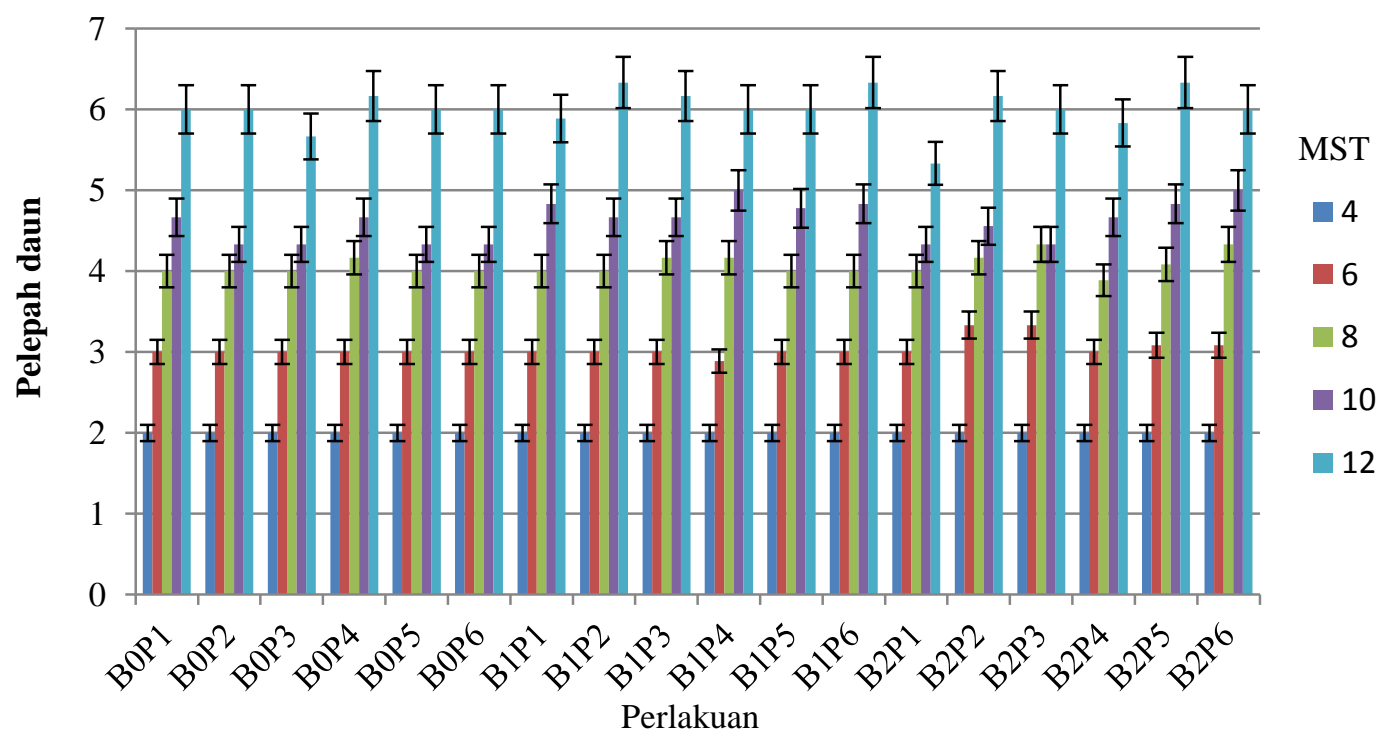

Gambar 3. Pengaruh pupuk organik hayati pelarut fosfat terhadap pelepah daun bibit kelapa sawit pada 4 - 12 MST

Laju pertumbuhan pelepah daun kelapa sawit terbaik selama pengamatan ditunjukkan oleh kombinasi pupuk organik dengan SP-36 dosis 100\% (B1P6). Namun tidak demikian dengan kombinasi perlakuan pupuk organik hayati maupun pupuk organik dengan batuan fosfat, bahkan jumlah pertumbuhan pelepah daun kelapa sawit pada kombinasi perlakuan pupuk organik hayati dengan batuan fosfat dosis 50\% (B2P1) menunjukkan nilai pertambahan pelepah daun terendah. Hal tersebut juga semakin membuktikan bahwa SP-36 memang pupuk sumber $\mathrm{P}$ yang sangat mudah diserap oleh tanaman. Soepardi (1983) mengemukakan peranan P antara lain penting untuk pertumbuhan sel, pembentukan akar halus dan rambut akar, memperkuat batang agar tanaman tidak mudah rebah, memperbaiki kualitas tanaman, pembentukan bunga, buah dan biji serta memperkuat daya tahan terhadap penyakit.

Hasil analisa statistika terhadap data keragaan tanaman pada 12 MST yang disajikan pada Tabel 2 menunjukkan bahwa pemberian perlakuan memberikan pengaruh yang nyata. Secara berturut-turut hasil terbaik diameter bonggol, tinggi tanaman dan pelepah daun tanaman selalu ditunjukkan oleh perlakuan penggunaan pupuk organik dan organik hayati. Hasil pengamatan ini menunjukkan terjadinya peningkatan pertumbuhan keragaan tanaman perlakuan yang menggunakan pupuk organik/hayati sehingga pertumbuhan tanaman dapat optimal.

Hasil analisa statistik terhadap pengaruh tunggal penggunaan pupuk organik hayati tidak menunjukkan pengaruh yang nyata antar perlakuan baik terhadap diameter bonggol, tinggi tanaman dan jumlah pelepah daun tanaman. Namun bila dilihat lebih detail pada hasil data pengukuran diameter dan tinggi tanaman, pengaruh tunggal hasil terbaiknya selalu ditunjukkan oleh penggunaan pupuk organik hayati. Hal ini diduga pupuk organik hayati dapat memberikan lingkungan yang mendukung untuk pertumbuhan mikrob tanah, seperti diungkapkan Rosmarkam dan Yuwono (2002) bahwa aktivitas mikrob tanah mempengaruhi sifat kesuburan tanah, baik sifat fisik, sifat kimia serta sifat biologi tanah.

Hasil analisa statistik terhadap pengaruh tunggal faktor sumber hara fosfat menunjukkan penggunaan batuan fosfat sebagai alternatif pupuk sumber $P$ menunjukkan hasil yang lebih baik dibanding penggunaan pupuk SP-36 terhadap diameter bonggol dan tinggi tanaman walau masih dalam taraf tidak berbeda nyata. Penggunaan pupuk batuan fosfat dapat dilakukan bersamaan dengan penggunaan pupuk organik hayati agar mendapatkan hasil yang optimal. Hal ini sejalan dengan pendapat Winarso (2005) yaitu sifat P di dalam tanah 
terdapat dalam berbagai bentuk persenyawaan yang sebagian tidak tersedia bagi tanaman, sehingga pemberian pupuk organik/hayati dapat membantu proses mineralisasi $\mathrm{P}$ dalam tanah agar dapat tersedia bagi tanaman.

Tabel 2. Pengaruh pupuk organik hayati pelarut fosfat terhadap keragaan bibit kelapa sawit pada 12 MST

\begin{tabular}{|c|c|c|c|}
\hline \multirow[t]{2}{*}{ Perlakuan } & \multicolumn{3}{|c|}{ Keragaan Tanaman 12 MST } \\
\hline & Diameter $(\mathrm{mm})$ & Tinggi $(\mathrm{cm})$ & Pelepah daun tanaman $^{-1}$ \\
\hline \multicolumn{4}{|l|}{ Pengaruh Tunggal } \\
\hline Tanpa Pupuk Organik & $15.79 \mathrm{a}$ & $42.47 \mathrm{a}$ & $5.98 \mathrm{a}$ \\
\hline Pupuk Organik & $16.59 \mathrm{a}$ & $42.20 \mathrm{a}$ & $6.12 \mathrm{a}$ \\
\hline Pupuk Organik Hayati & $16.70 \mathrm{a}$ & $44.02 \mathrm{a}$ & $5.93 \mathrm{a}$ \\
\hline Batuan Fosfat & $16.39 \mathrm{a}$ & $43.02 \mathrm{a}$ & $5.95 \mathrm{a}$ \\
\hline SP-36 & $16.33 \mathrm{a}$ & $42.77 \mathrm{a}$ & $6.07 \mathrm{a}$ \\
\hline \multicolumn{4}{|l|}{ Pengaruh Kombinasi } \\
\hline Batuan fosfat $50 \%$ & $16.48 \mathrm{abcd}$ & 43.25 abcd & $6.0 \mathrm{ab}$ \\
\hline Batuan fosfat $75 \%$ & $16.07 \mathrm{abcd}$ & $42.13 \mathrm{abcd}$ & $6.0 \mathrm{ab}$ \\
\hline Batuan fosfat $100 \%$ & $15.41 \mathrm{bcd}$ & $40.72 \mathrm{~cd}$ & $5.7 \mathrm{ab}$ \\
\hline SP-36 $50 \%$ & $16.41 \mathrm{abcd}$ & 42.33 abcd & $6.2 \mathrm{ab}$ \\
\hline SP-36 $75 \%$ & $15.01 \mathrm{~d}$ & 43.62 abcd & $6.0 \mathrm{ab}$ \\
\hline SP-36 $100 \%$ & $15.38 \mathrm{~cd}$ & 42.77 abcd & $6.0 \mathrm{ab}$ \\
\hline Pupuk organik + Batuan fosfat $50 \%$ & $16.85 \mathrm{abcd}$ & $42.34 \mathrm{abcd}$ & $5.9 \mathrm{ab}$ \\
\hline Pupuk organik + Batuan fosfat $75 \%$ & $16.29 \mathrm{abcd}$ & 42.87 abcd & $6.3 \mathrm{a}$ \\
\hline Pupuk organik + Batuan fosfat $100 \%$ & $16.00 \mathrm{abcd}$ & 43.94 abcd & $6.2 \mathrm{ab}$ \\
\hline Pupuk organik + SP-36 $50 \%$ & $16.07 \mathrm{abcd}$ & $41.49 \mathrm{abcd}$ & $6.0 \mathrm{ab}$ \\
\hline Pupuk organik + SP-36 $75 \%$ & $16.17 \mathrm{abcd}$ & $38.58 \mathrm{~d}$ & $6.0 \mathrm{ab}$ \\
\hline Pupuk organik + SP-36 $100 \%$ & $18.15 \mathrm{a}$ & 43.97 abcd & $6.3 \mathrm{a}$ \\
\hline Pupuk organik hayati + Batuan fosfat $50 \%$ & $15.80 \mathrm{abcd}$ & $41.47 \mathrm{bcd}$ & $5.3 \mathrm{ab}$ \\
\hline Pupuk organik hayati + Batuan fosfat $75 \%$ & $17.09 \mathrm{abc}$ & 43.66 abcd & $6.2 \mathrm{~b}$ \\
\hline Pupuk organik hayati + Batuan fosfat $100 \%$ & $17.51 \mathrm{ab}$ & $46.83 \mathrm{a}$ & $6.0 \mathrm{ab}$ \\
\hline Pupuk organik hayati + SP-36 $50 \%$ & $16.41 \mathrm{abcd}$ & 42.72 abcd & $5.8 \mathrm{ab}$ \\
\hline Pupuk organik hayati + SP-36 $75 \%$ & $16.47 \mathrm{abcd}$ & $44.59 \mathrm{abc}$ & $6.3 \mathrm{a}$ \\
\hline Pupuk organik hayati + SP-36 $100 \%$ & $16.94 \mathrm{abcd}$ & $44.87 \mathrm{ab}$ & $6.0 \mathrm{ab}$ \\
\hline
\end{tabular}

Keterangan: Angka yang ditandai dengan huruf yang sama pada setiap kolom menunjukkan hasil yang tidak berbeda nyata menurut uji Duncan pada taraf nyata 0.05 .

\section{Peubah Populasi Total Mikrob dan Populasi Mikrob Pelarut Fosfat}

Hasil analisa statististik terhadap pengaruh tunggal penggunaan pupuk organik hayati pelarut fosfat terhadap populasi total mikrob tanah pada Tabel 3 menunjukkan hasil yang berbeda nyata dengan hasil terbaik ditunjukkan oleh penggunaan pupuk organik (B1). Telah lama diketahui bahwa bahan organik memiliki efek yang menguntungkan pada pertumbuhan tanaman yaitu untuk pertambahan nutrisi. Menurut Kumazawa (1984) bahan organik mengandung berbagai jenis nutrisi tanaman, baik unsur hara makro maupun mikro.

Tabel 3. Pengaruh pupuk organik hayati terhadap populasi total mikrob dan mikrob pelarut fosfat (MPF) pada 22 MST

\begin{tabular}{|c|c|c|}
\hline \multirow[t]{2}{*}{ Perlakuan } & \multicolumn{2}{|c|}{ Populasi Mikrob Tanah SPK g $^{-1}$} \\
\hline & Total Mikrob $10^{6}$ & MPF $10^{3}$ \\
\hline \multicolumn{3}{|l|}{ Pengaruh Tunggal } \\
\hline Tanpa pupuk organik/hayati & $36.71 \mathrm{ab}$ & $0.78 \mathrm{a}$ \\
\hline Pupuk organic & $46.64 \mathrm{a}$ & $0.59 \mathrm{a}$ \\
\hline Pupuk organik hayati & $25.20 \mathrm{~b}$ & $0.49 \mathrm{a}$ \\
\hline Batuan fosfat & $36.57 \mathrm{a}$ & $0.40 \mathrm{a}$ \\
\hline SP-36 & $35.80 \mathrm{a}$ & $0.84 \mathrm{a}$ \\
\hline \multicolumn{3}{|l|}{ Pengaruh Kombinasi } \\
\hline Batuan fosfat $50 \%$ & $44.68 \mathrm{ab}$ & $0.08 \mathrm{a}$ \\
\hline Batuan fosfat $75 \%$ & $19.78 \mathrm{ab}$ & $0.18 \mathrm{a}$ \\
\hline Batuan fosfat $100 \%$ & $18.47 \mathrm{~b}$ & $0.35 \mathrm{a}$ \\
\hline SP-36 $50 \%$ & $36.78 \mathrm{ab}$ & $0.42 \mathrm{a}$ \\
\hline SP-36 $75 \%$ & $41.61 \mathrm{ab}$ & $2.17 \mathrm{a}$ \\
\hline SP-36 $100 \%$ & $58.93 \mathrm{ab}$ & $1.50 \mathrm{a}$ \\
\hline Pupuk organik + Batuan fosfat $50 \%$ & $44.79 \mathrm{ab}$ & $0.33 \mathrm{a}$ \\
\hline Pupuk organik + Batuan fosfat $75 \%$ & $60.47 \mathrm{a}$ & $0.83 \mathrm{a}$ \\
\hline Pupuk organik + Batuan fosfat $100 \%$ & $59.67 \mathrm{a}$ & $0.50 \mathrm{a}$ \\
\hline Pupuk organik + SP-36 $50 \%$ & $28.98 \mathrm{ab}$ & $0.43 \mathrm{a}$ \\
\hline Pupuk organik + SP-36 $75 \%$ & $44.43 \mathrm{ab}$ & $0.61 \mathrm{a}$ \\
\hline Pupuk organik + SP-36 $100 \%$ & $41.50 \mathrm{ab}$ & $0.83 \mathrm{a}$ \\
\hline Pupuk organik hayati + Batuan fosfat $50 \%$ & $28.63 \mathrm{ab}$ & $0.61 \mathrm{a}$ \\
\hline Pupuk organik hayati + Batuan fosfat $75 \%$ & $31.93 \mathrm{ab}$ & $0.26 \mathrm{a}$ \\
\hline Pupuk organik hayati + Batuan fosfat $100 \%$ & $20.73 \mathrm{ab}$ & $0.43 \mathrm{a}$ \\
\hline Pupuk organik hayati + SP-36 $50 \%$ & $20.03 \mathrm{ab}$ & $0.60 \mathrm{a}$ \\
\hline Pupuk organik hayati + SP-36 $75 \%$ & $30.07 \mathrm{ab}$ & $0.52 \mathrm{a}$ \\
\hline Pupuk organik hayati + SP-36 $100 \%$ & $19.79 \mathrm{ab}$ & $0.53 \mathrm{a}$ \\
\hline
\end{tabular}

Keterangan: Angka yang ditandai dengan huruf yang sama pada setiap kolom menunjukkan hasil yang tidak berbeda nyata menurut uji Duncan pada taraf nyata 0.05 . 
Pada pengaruh kombinasi analisa populasi total mikrob hasil analisis statistik menunjukkan pengaruh yang nyata, denganhasil terbaik ditunjukkan oleh perlakuan kombinasi pupuk organik dengan batuan fosfat (B1P2, B1P3). Hasil yang diperlihatkan pada analisa populasi total mikrob diduga karena ketersediaan $\mathrm{P}$ organik bagi tanaman sangat tergantung pada aktivitas mikrob untuk memineralisasikannya. Namun seringkali hasil mineralisasi ini segera bersenyawa dengan bagian-bagian anorganik untuk membentuk senyawa yang relatif sukar larut, diketahui fosfat anorganik dapat diimmobilisasi menjadi P-organik oleh mikrob dengan jumlah yang bervariasi antara 25-100 \% (Havlin et al., 1999).

Selanjutnya hasil analisis statistik populasi mikrob pelarut fosfat (MPF) menunjukkan hasil yang tidak berbeda nyata pada semua perlakuan. Hasil tersebut karena efektifitas mikrob pelarut $\mathrm{P}$ tidak hanya disebabkan kemampuannya dalam meningkatkan ketersediaan P tetapi juga memiliki kemampuan dalam menghasilkan zat pengatur tumbuh, terutama pada mikrob yang hidup dipermukaan akar seperti Pseudomonas fluorescens, $P$. putida dan $P$. striata. Mikrob tersebut dapat menghasilkan zat pengatur tumbuh seperti asam indol asetat dan asam giberelin (Patten dan Glick, 1996), hal tersebut dimungkinkan MPF terdeteksi pada berbagai mikro habitat tanaman sehingga pelaksanaan pengambilan sampel untuk analisa MPF sangat perlu diperhatikan agar hasil analisa populasi MPF dapat lebih baik.

Diketahui beberapa mekanisme dalam pelarutan fosfat oleh mikrob pelarut fosfat adalah: (1) produksi asam-asam organik, (2) pemasaman $\mathrm{pH}$ medium yang disebabkan oleh ekskresi $\mathrm{H}^{+}$oleh bakteri, (3) enzim fosfatase yang dihasilkan mikrob (De Freitas et al., 1997). Enzim fosfatase berperan utama dalam melepaskan P dari ikatan P-organik. Enzim ini banyak dihasilkan dari mikrob tanah, terutama yang bersifat heterotroph, sel-sel mikrob sangat kaya dengan asam nukleat. Jika mikrob mati, maka asam nukleat siap untuk dimineralisasi (Alexander, 1978).

\section{SIMPULAN}

Efektifitas mikrob pelarut fosfat (MPF) menunjukkan hasil yang tidak berbeda nyata pada semua perlakuan. Pengaruh kombinasi penggunaan pupuk batuan fosfat terhadap tinggi tanaman menunjukkan hasil yang lebih baik dibandingan penggunaan SP-36 dan pengaruh tunggal penggunaan pupuk organik hayati terhadap total populasi mikrob tanah menunjukkan hasil terbaik.

\section{UCAPAN TERIMA KASIH}

Terima kasih penulis ucapkan kepada PT. Swakarsa Sinar Sentosa atas berbagai dukungan materil untuk pelaksanaan penelitian juga kepada PT. Sitosu Agro Cemerlang atas bantuan pupuk organik hayati "Biost" yang digunakan dalam penelitian.

\section{DAFTAR PUSTAKA}

Adiningsih, J. 1992. Peranan efisiensi pengunaan pupuk untuk melestarikan swasembada pangan. Orasi Pengukuhan Ahli Peneliti Utama. Bogor, 24 april 1992.

Agung, T. dan A.T. Rahayu. 2004. Analisis efisiensi serapan N, pertumbuhan dan hasil beberapa kultivar kedelai unggul baru dengan cekaman kekeringan dan pemberian pupuk hayati. JMA., 6:70-74.

Alexander, M. 1978. Introduction to Soil Microbiology. $2^{\text {nd }}$ ed. Willey Eastern Limited, New Delhi.

Boggs, L.C., A.C. Kennedy, and I.P. Reganold. 2000. Organic and biodynamic management effect on soil biology. J Soil Sci Soc Am., 64 : 1651-1659.

De Freitas, J.R., M.R. Banerjee, and J.J. Germida. 1997. Phosphate-solubilizing rhizobacteria enhance the growth and yield but not phosphorus uptake of canola (Brassica napus L). J Biol Ferti Soils., 24:358-364.

El-Habbasha, S.F., M.S. Abd El Salam, and M.O. Kabesh. 2007. Response of two sesame varieties (Sesamum indicum L) to partial replacement of chemical fertilizers. JABS., 3: 563-571.

Hardjowigeno, S. 1995. Ilmu Tanah. Aka Pr. Jakarta. 126 hlm.

Havlin, J.L., J.D. Beaton, S.L. Tisdale, and W.L. Nelson. 1999. Soil Fertility and Fertilizers. $6^{\text {th }}$ Edition. Prentice Hall. Upper Saddle River, NJ. 499 p.

Hindersah, R., dan T. Simarmata. 2004. Ulas balik potensi rizobakteri Azotobacter dalam meningkatkan kesehatan tanah. J Natur Indonesia, 5: 127-133.

Kiswanto, J.H., Purwanta, dan B. Wijayanto. 2008. Teknologi Budidaya Kelapa Sawit. Balai Pengkajian Teknologi Pertanian. Bandar Lampung.

Kumazawa, K. 1984. Beneficial Efects of Organic Matter on Rice Growth and Yield in Japan. In Organic Matter AND Rice. IRRI. Los Banos, Laguna, Phillipines. p. 431-444.

Lee, Sunhee, A. Reth, D. Meletzus, M. Sevilla, and C. Keneddy. 2000. Characterization of a major cluster of nif, fix and associated genes in Sugarcane Endhopyte, Acetobacter diazhotropicus. $J$ Bacteriology, 182: 7088 - 7091.

Mattjik, A.A., dan I.M. Sumertajaya. 2006. Perancangan Percobaan dengan Aplikasi SAS dan Minitab. IPB Pr. Bogor. 271 hlm.

Patten, C.L. and B.R. Glick. 1996. Bacterial biosynthesis of indole-3-acetic acid. J Microbiol, 42:207-220. 
Rosmarkam dan Yuwono. 2002. Ilmu Kesuburan Tanah. Kanisius. Yogyakarta.

Smith, J.L., R.I. Rapendick, D.F. Bezdicek, and J.M. Lynch. 1993. Soil organic matter dynamics and crop residue management [editorial]. Soil Microbial Ecology. Marcel Dekker Inc. p: 65-94.

Smith, S.E., and D.J. Read. 1997. Mychorizal Symbiosis. Academic Pr., London.
Soepardi, G. 1983. Sifat dan Ciri Tanah. IPB Press. Bogor.

Subba Rao, N.S. 1994. Biofertilizer in Agricultural: Oxford and IBH Publishing Co., New Delhi.

Winarso, S. 2005. Kesuburan Tanah Dasar Kesehatan dan Kualitas Tanah. Penerbit Gava Media. Yogyakarta. 